\title{
The Relationship between the Management Intervention of Venture Capital Institutions and the Performance of Start-Up Enterprises
}

\author{
Yan Wang \\ Department of Finance, Jinan University, Guangzhou, China \\ Email:wyway957@163.com
}

How to cite this paper: Wang, Y. (2019) The Relationship between the Management Intervention of Venture Capital Institutions and the Performance of Start-Up Enterprises. Modern Economy, 10, 666-678. https://doi.org/10.4236/me.2019.103045

Received: February 20, 2019

Accepted: March 12, 2019

Published: March 15, 2019

Copyright (อ 2019 by author(s) and Scientific Research Publishing Inc. This work is licensed under the Creative Commons Attribution International License (CC BY 4.0).

http://creativecommons.org/licenses/by/4.0/

\section{(c) (i) Open Access}

\begin{abstract}
Based on the two theoretical hypotheses of "screening theory" and "cultivation theory", this paper reviews the concepts and motivations of venture capital institutions' management intervention, and summarizes the two modes of venture capital institution management intervention: supervisory control intervention and operational management intervention. Based on two management intervention modes, this paper divides the management involvement into three levels: no management intervention, moderate management intervention, and deep management intervention. This paper systematically analyzes the influence mechanism of the two management intervention modes and the degree of involvement on the performance of venture enterprises, and constructs a comprehensive theoretical framework of venture capital and entrepreneurial enterprise performance, which provides theoretical support and research direction for follow-up research.
\end{abstract}

\section{Keywords}

Supervisory Control Intervention, Operational Management Intervention, The Degree of Involvement

\section{Introduction}

Venture capital rose in the United States in the 1940s, and most of its investment targets are small and medium-sized enterprises in the start-up period. However, start-ups usually have great risks and uncertainties, and there is information asymmetry between them. Therefore, venture capital institutions generally participate in the management of start-ups after investment (Hallen, 2008) [1], while the nature of equity investment determines that venture capital institu- 
tions have legitimate management rights to start-ups. Venture capital institutions often rely on their own industry expertise and experience to engage in corporate management by assigning directors, supervisors, senior managers and professional technicians to improve the survival rate of start-ups and improve the performance of start-ups and their own return on investment.

Previously, scholars have conducted some discussions on the subject of the impact of venture capital institutions on the performance of entrepreneurial enterprises, forming two mainstream views of "screening theory" and "cultivation theory". However, most of the research on these two mainstream views focuses on the "ex ante selection" effect of venture capital and the value-added services or regulatory control provided by venture capital. In the research based on management intervention, most of them are involved in the research of venture capital institutions involved in the board of directors of the enterprise, but the management intervention of supervisors, senior managers and professional technicians, and the comprehensive analysis of the degree of management intervention is rarely involved. It provides an expandable space for the research in this paper. This paper attempts to analyze the impact of the management intervention and the degree of involvement on the performance of venture enterprises by establishing a theoretical framework. It has important theoretical and practical significance for supplementing and expanding the research scope of venture capital, guiding post-investment management of venture capital, and promoting the performance improvement of entrepreneurial enterprises.

This paper mainly analyzes the impact of the management intervention of venture capital and its degree of involvement on the performance of start-up enterprises. According to the combing and summarization of the existing literature, this paper divides the management intervention into supervisory control intervention and operational management intervention. On this basis, the management intervention degree of venture capital institutions is divided into three levels: no management intervention, moderate management intervention, deep management intervention. Based on the existing literature, this paper attempts to answer the following questions: First, what are the management intervention models of venture capital institutions? Second, what impact does each type of management intervention model of a venture capital institution have on the performance of a startup? Third, whether and how the degree of management involvement of venture capital institutions affect on corporate performance?

Specifically, the content of this paper is arranged as follows. The first part is the introduction, which briefly describes the relevant background and proposes analysis problems. The second part is the theoretical hypothesis that venture capital affects the performance of entrepreneurial enterprises, including "screening theory" and "cultivation theory". The third part is the analysis of the mechanism of risk investment institution management intervention affecting the performance of venture enterprises, including the definition, motivation, mode and mechanism of the management intervention of venture capital institutions. The fourth part is the construction of theoretical model. The fifth part is the 
prospect of future research.

\section{The Theoretical Hypothesis That Venture Capital Affects the Performance of Entrepreneurial Enterprises}

At present, domestic and foreign scholars have formed two mainstream views on the relationship between venture capital and entrepreneurial enterprise performance: "screening theory" and "cultivation theory". A large amount of research has been carried out in the academic world around these two viewpoints.

\subsection{Screening Theory}

As far as "screening theory" is concerned, experienced and professional venture capital institutions can screen out the real potential enterprises by screening mechanisms to avoid the adverse selection of high-risk and information-asymmetric startups (Amit et al., 1998) [2]. Therefore, the increase in the performance of the company is due to the strength and efforts of the company itself, rather than the involvement of venture capital institutions. In addition, the earlier the venture capital institution enters the venture, the more prominent the role of "screening"; the later the entry into the venture, the smaller the risk and uncertainty of the venture, and the "screening" role of the venture capital institution will be greatly weaken (Gou \& Dong , 2013) [3].

Fried \& Hisrich (1994) found that venture capital institutions generally conduct strict and prudent investigations before capital injection to identify the quality of management teams and businesses, and to supervise and control startups [4]. Rosa et al. (2003) also compared the operating performance of venture companies with or without venture capital investment and found that there is no significant difference between the two business performances, that is, the participation of venture capital institutions can not promote the growth of entrepreneurial performance. Busenitz et al. (2004) argue that venture capital institutions have special industry attributes that will provide some value-added services to enterprises, but will not have a significant impact on long-term performance. Brau et al. (2004) took the manufacturing enterprises as the research object, and found that there was no significant difference between SMEs that were involved in venture capital institutions and those involved in risk-free investment institutions [5].

\subsection{Cultivation Theory}

As far as the "cultivation theory" is concerned, venture capital institutions generally spend a lot of time participating in business management, making major decisions and resolutions, providing enterprises with non-capital value-added services in all aspects (Gorman \& Sahlman, 1989) and carrying out the necessary supervisory control (Baker \& Gompers, 2003) [6] [7]. This kind of management intervention must have a direct impact on corporate performance, which may be positive or negative.

Most scholars believe that venture capital can have a positive impact on the 
business performance of the company and analyze its impact path. 1) In terms of supervision and control. Campbell \& Frye (2009) found that the involvement of venture capital will improve the governance level of startups in the years before and after listing, but the impact will disappear after the exit of venture capital. Jain \& Kini (1995) empirically found that the performance of startups with venture capital institutions after 3 years of listing is better than that of venture-free investment institutions [8]. The main reason is that venture capital generally supervises and controls the invested companies. Stein \& Bygrave (1990) used 77 entrepreneurial companies as a sample of research and found that the more seats a venture capital institution has on a board of a startup, the higher the performance of the startup. 2) In terms of operations management. Fitza \& Mosakowski (2009) believes that startups often lack business experience, so the help of venture capital firms with extensive experience and industry expertise is critical to the success of the invested company [9]. Inderst \& Mueller (2009) found that companies supported by venture capital in an imperfectly competitive market will develop at a faster rate in the initial stage; companies supported by venture capital in a perfectly competitive market will be better in the long-term sustainable development [10]. Zaborowski (2009) studied the mechanism of venture capital investment in the United States to promote high-tech development, and found that venture capital institutions can help startups improve their finances and build a reputation [11]. Colombo et al. (2016) found that venture capital institutions use their own resource networks to make it easier for startups to obtain capital, information, technology, trust, etc, and to promote the rapid increase in the value of startups [12].

However, some scholars believe that venture capital will have a negative impact on the business performance of the company. Venture companies with venture capital participation have not shown better performance (Bottazzi \& Rin, 2002) because when a venture capital institution has the willingness to provide some assistance to the management of the invested company, it may create a conflict of control with the original entrepreneurial management team [13]. The higher the degree of participation of venture capital institutions in business management, the worse the performance of the company will be (Higashide \& Birley, 2002) [14]. Gomez-Mejia et al. (1990) conducted several interviews with CEOs of startups and found that CEOs agree with the financial and cyber roles of venture capitalists, but the management roles of venture capitalists are mixed, and some of the CEOs even think that the management involvement of venture capitalists has hindered the further development of enterprises [15].

\section{Mechanism Analysis of Venture Capital Institutions' Management Intervention Affecting the Performance of Startups}

\subsection{Definition of Management Involvement of Venture Capital Institutions}

The broad management intervention refers to a series of management participa- 
tion activities carried out by venture capitalists on venture enterprises after injecting funds into enterprises according to investment agreements (Tyebjee \& Bruno, 1984), including strategic support, network resource support, operational support, and human resource support (Sapienza et al., 1994; Knockaert et al., 2005) [16] [17] [18]. Narrowly defined management intervention means that venture capital institutions enter the invested enterprise by assigning personnel to perform related functional management, including the placement of directors, supervisors, senior managers, professional technicians, etc. (Gorman \& Sahlman, 1989; Macmilan et al., 1989) [6] [19]. Directors are the main force of internal corporate governance. Supervisors are members of a permanent supervisory body in the company. senior managers refer to the company's manager, deputy manager, financial controller, board secretary of the listed company, and other personnel as stipulated in the company's articles of association; Professional technicians are professionals who are engaged in professional work with their professional skills, and thus receive corresponding benefits, including financial personnel, technical research and development personnel, legal personnel, and risk control personnel, etc. The management involvement of venture capital institutions referred to in this paper is the narrowly involved management intervention.

\subsection{Motivation of Management Involvement of Venture Capital Institutions}

The reason why venture capital institutions actively participate in the management of invested companies and conduct comprehensive supervision is to obtain high return on investment. This paper believes that the main reasons for venture capital institutions to intervene in enterprise management are the following aspects.

1) The disadvantages of newcomers in start-ups

The disadvantages of newcomers in start-ups are that startups often face many problems such as lack of resources, inadequate internal organizational systems, low organizational identity, external network connections that is limited and very unstable, low reputation and legitimacy (Hallen, 2008) [1]. The disadvantages of the new-born entrepreneurs lead to their deficiencies in human resource management, mainly reflected in the contradiction between the lack of human resources in entrepreneurial enterprises and the demand for high-quality talents.

2) Information asymmetry of venture capital

According to the information asymmetry theory, there is information asymmetry between venture capital institutions and entrepreneurial enterprises, which may lead to adverse selection and moral hazard. On the one hand, information asymmetry may lead to resource mismatches in the market, which in turn leads to adverse selection between venture capital institutions and start-ups. On the other hand, information asymmetry may cause the invested company to harm the interests of venture capital institutions in the course of business operations, so that venture capital institutions face moral hazard problems. Based on 
this, more and more venture capital institutions are more actively involved in enterprise management, supervising and managing the daily operations and production activities of enterprises, so that the operation and development of enterprises are consistent with their own interests.

3) Professional advantage of venture capital institutions

Amit \& Muller (1993) argues that venture capital institutions generally have extensive experience and skills to operate in highly uncertain and information-asymmetric environments [20]. Venture capital institutions generally bring together professionals in investment, operations and management. They can comprehensively assess the overall situation of start-ups, use their own resources and social networks, and inject professional and powerful management power into the invested companies, and design a good incentive and restraint mechanism to make the invested companies consistent with venture capital institutions' interests.

\subsection{Mode of Venture Capital Management Intervention}

Amit et al. (1998) argue that because of the uncertainty of entrepreneurial firms, the human capital of venture capital firms and start-ups needs to maximize synergies to reduce the uncertainty of startups [2]. According to the combing and summarization of the existing literature, this paper divides the management intervention mode of venture capital institutions into two types: supervisory control intervention and operational management intervention.

1) Supervised control intervention

This article will delegate the involvement of directors and supervisors in enterprise management as a form of management intervention, that is, supervisory control intervention. The board of directors is the most important decisionmaking and management body, and Gorman \& Sahlman (1989) pointed out that almost all venture capital institutions want to occupy a greater position and influence on the board of the startup [6]. As the company's special supervision organization, the board of supervisors can not only help shareholders to supervise managers, but also form a balance of pressure on the board of directors to a certain extent. Therefore, the involvement of directors and supervisors in enterprise management is an important way for venture capital institutions to supervise and control.

2) Operational management intervention

This article will delegate the involvement of senior managers and professional technicians in enterprise management as a form of management intervention, namely operational management intervention. Dushnitsky \& Lavie (2010) found that venture capital institutions generally bring together professionals in investment, operations and management [21]. They know more about the industry and management, so they can recommend suitable senior managers for startups, even directly station senior managers, to improve the value of startups. In addition, venture capital institutions will also participate in the recruitment of cor- 
porate personnel to help companies recruit the employees needed for day-to-day operations.

\subsection{The Mechanism of the Involvement of Venture Capital Institutions in the Performance of Venture Enterprises}

1) The impact of supervisory control intervention on the performance of entrepreneurial enterprises

Uncertainty and agency theory believe that venture capital institutions can supervise and control corporate governance and business activities of start-ups, which can improve the independence of corporate governance structure (Bouresli \& Abdulsalam, 2002; Baker \& Gompers, 2003) and reduce agency risk (Arcot \& Sridha, 2014; Bernstein, 2016) [7] [22] [23] [24]. It is an important driver of increased return on investment. By assigning directors or supervisors to the invested companies and providing intensive monitoring services, the venture capital institution can reduce the agency costs and risk losses caused by the uncertainty of the start-ups and improve its performance (Barry et al., 1990) [25].

Stein \& Bygrave (1990) found that venture capital institutions with more board seats can participate in corporate management to increase the value of start-ups. Ni Jinging (2012) found that the proportion of supervisors appointed by venture capital institutions has a significant role in promoting the profitability of entrepreneurial enterprises [26]. However, some scholars have found that some CEOs do not think that the contribution of directors from venture capital institutions is higher than that of other board members (Rosenstein et al., 1993), and some CEOs even think that venture capitalists' interventions in management hindered the development of start-ups (Gomez-Mejia et al., 1990) [27] [15]. Hu et al. (2010) found that due to the concentration of equity, the board of supervisors had a negative impact on the performance of Chinese listed companies [28]. Despite the differences in the quantitative methods of return on investment, the perceived bias of the respondents and the differences in research methods, the existing research shows that the participation of directors and supervisors assigned by venture capital institutions in corporate management has indeed increased the value of entrepreneurial enterprises in most cases.

2) Impact of operational management intervention on the performance of entrepreneurial enterprises

Resource capacity and social network theory believe that venture capital institutions usually have knowledge and skills in certain professional fields. They can rely on their own resources, capabilities and networks to help start-up companies establishing competitive advantages and creating more values by assigning senior managers and professional technicians to participate in company management (Dushnitsky \& Lavie, 2010; Dutta \& Folta, 2016) [21] [29]. Based on foreign data samples, some scholars have verified that based on their own resource endowments and industry expertise, VC institutions recommend senior managers to start-up enterprises and even directly dispatch senior managers or professional technicians to actively participate in the management activities of 
the invested enterprises, which can create value for the business (Rosenstein et al., 1993; Tian et al., 2016) [26] [30]. Hellmann \& Puri (2002) found that VC institutions will replace founders by assigning professional CEOs to provide more professional value-added services to start-ups and optimize company performance [31]. At the same time, the author believes that entrepreneurs should give VC institutions greater rights in exchange for better management.

3) The influence of the degree of management involvement of venture capital institutions on the performance of entrepreneurial enterprises

Macmillan et al. (1989) classified the venture capital institutions into closely related, medium-intervention and laissez-faire according to the degree of involvement of venture capital firms [19]. The empirical results show that the three levels of intervention have different correlations with the operating performance of the invested companies: closely following companies have the best performance, and laissez-faire companies have the worst performance. The higher the degree of involvement of venture capital institutions, the more comprehensive the management services that can be provided to the invested companies. It can provide supervision on the strategy formulation, post-financing, personnel arrangement and marketing of the invested company, and also provide some help in supplier relations and daily management. On this basis, this paper divides the degree of management involvement of VC institutions into three levels: no management intervention, that is, venture capital institutions only provide financial support without intervention in entrepreneurial enterprise' management; moderate management intervention, that is, venture capital institutions only conduct supervisory control intervention or operational management intervention; deep management intervention, that is, the venture capital institution simultaneously carries out supervisory control intervention and operational management intervention.

\section{Theoretical Model Construction}

According to the systematic review of the existing literature, this paper reviews and summarizes the motivations, modes and mechanisms of risk investment management intervention based on the two theoretical hypotheses of "screening theory" and "cultivation theory". After further research, this paper proposes a theoretical analysis framework for venture capital to influence the performance of entrepreneurial enterprises (Figure 1).

According to the above theoretical analysis model, the following conclusions can be drawn:

1) For the measurement of the performance of entrepreneurial enterprises, most literatures will choose to use the principal component analysis or factor analysis method to obtain the comprehensive performance score, mainly from the four aspects of the company's asset operation ability, solvency, profitability and development potential. To improve the indicator composition, this theoretical framework has added the ability of innovation. The current research mainly 


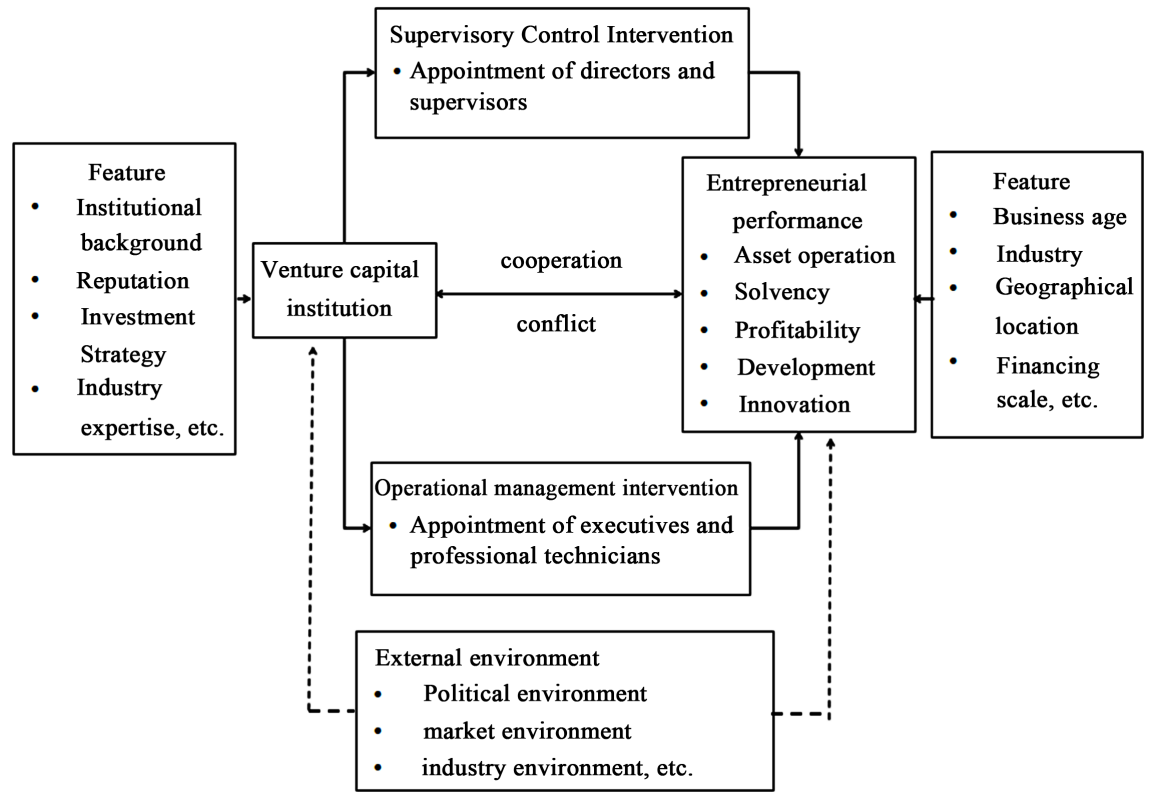

Figure 1. The theoretical framework of the management involvement of venture capital institutions affecting the performance of venture enterprises.

focuses on the capital's profitability and innovation ability of entrepreneurial enterprises, and has not formed a unified conclusion.

2) From the characteristics of venture capital institutions and start-up enterprises. The characteristics of the venture capital institution's institutional background, reputation level, investment strategy, industry expertise, as well as the age, industry, geographical location, and financing scale of the startups will all affect the degree and quality of the management involvement on the venture enterprise, which in turn affects the performance of the startup enterprise. The current literature has some research on some related characteristics. For example, for the investment strategy of venture capital institutions, some scholars have found that if the feasibility of an investment is relatively certain, the venture capital institution will generally choose independent investment; if the feasibility of the investment project cannot be confirmed, venture capital firms tend to choose to use multiple agencies to invest in joint ventures (Kelly \& Hay, 2000; $\mathrm{Gu} \& \mathrm{Lu}, 2014$ ) [32] [33]; in an incomplete market, phased investment can provide venture capital institutions with the option of terminating investment projects, thereby helping venture capital institutions minimize agency costs (Sahlman, 1990) [34].

3) From the perspective of the mechanism of the involvement of venture capital institutions in the performance of entrepreneurial enterprises. Although there is no empirical data to verify, it is possible to construct a basic mechanism through theoretical analysis and empirical derivation. The venture capital institution's management intervention modes for venture enterprises divides into two types: supervisory control intervention and operational management intervention. supervisory control intervention, that is, by entrusting directors and 
supervisors to enter the invested enterprise, strengthen supervision and control over the invested enterprise, reduce the agency cost and risk loss caused by the uncertainty of the startup enterprise, and improve the performance of the enterprise. Operational management intervention, that is, by assigning senior managers and professional technicians to the invested enterprise, providing more targeted services to the operation and management of the invested enterprise, thereby improving the overall performance of the enterprise. Based on two management intervention models, this paper divides the degree of management involvement of venture capital institutions into three levels: no management intervention, moderate management intervention, and deep management intervention. No management intervention, that is, venture capital institutions only provide financial support without intervening in the management of start-up enterprises; moderate management intervention, that is, venture capital institutions only conduct supervisory control intervention or operational management type intervention; deep management intervention, that is, the venture capital institution simultaneously carries out supervisory control intervention and operational management intervention. Different degrees of management involvement will have different effects on the performance of startups.

\section{Future Research Outlook}

On the whole, the theoretical framework and research system in this field have been outlined, but the corresponding research results are not systematic. Therefore, in the future, we need to enrich and develop the above research framework from the following directions.

1) By taking the supervisory control intervention, operational management intervention and management intervention degrees as the independent variables, taking the performance of the startup enterprises as the dependent variable and taking some characteristics of the venture capital institution and the startup enterprise as the control variables, an empirical test can be carried out on the theoretical model of the relationship between the management intervention, the degree of involvement and entrepreneurial performance. It can be used to analyze the rationality and effectiveness of the theoretical framework.

2) Further study of the mechanism of the relationship between the degree of management involvement of venture capital institutions and the performance of entrepreneurial enterprises. Investigate the relationship between the two by adding regulatory mechanisms, such as the industry expertise of venture capital firms and the degree of risk of startups. In theory, the higher the industry expertise of venture capital institutions, the more they tend to increase the degree of management involvement, and the better the performance of startup enterprises; the higher risk of the startup enterprise, the more venture capital institution tends to increase the degree of management involvement, and the worse the performance of the startup. In the next study, an empirical test can be conducted on this theoretical hypothesis. 


\section{Conflicts of Interest}

The author declares no conflicts of interest regarding the publication of this paper.

\section{References}

[1] Hallen, B.L. (2008) The Causes and Consequences of the Initial Network Positions of New Organizations: from Whom Do Entrepreneurs Receive Investments? Administrative Science Quarterly, 53, 685-718. https://doi.org/10.2189/asqu.53.4.685

[2] Amit, R., Brander, J. and Zott, C. (1998) Why Do Venture Capital Firms Exist? Theory and Canadian Evidence. Journal of Business Venturing, 13, 441-466. https://doi.org/10.1016/S0883-9026(97)00061-X

[3] Gou, Y.N. and Dong, J. (2013) Research on the Impact of Venture Capital Entry Time on Enterprise Technology Innovation. China Soft Science, 3, 132-140.

[4] Fried, V.H. and Hisrich, R.D. (1994) Toward a Model of Venture Capital Investment Decision Making. Fm the Journal of the Financial Management Association, 23, 28-37. https://doi.org/10.2307/3665619

[5] Brau, J.C., Brown, R.A. and Osteryoung, J.S. (2004) Do Venture Capitalists Add Value to Small Manufacturing Firms? An Empirical Analysis of Venture and Nonventure Capital-Backed Initial Public Offerings. Journal of Small Business Management, 42, 78-92. https://doi.org/10.1111/j.1540-627X.2004.00098.x

[6] Gorman, M. and Sahlman, W.A. (1989) What Do Venture Capitalists Do? Journal of Business Venturing, 4, 231-248. https://doi.org/10.1016/0883-9026(89)90014-1

[7] Baker, M. and Gompers, P. (2003) The Determinants of Board Structure at the Initial Public Offering. The Journal of Law and Economics, 46, 569-598. https://doi.org/10.1086/380409

[8] Jain, B.A. and Kini, O. (1995) Venture Capitalist Participation and the Post-Issue Operating Performance of IPO Firms. Managerial \& Decision Economics, 16, 593 606. https://doi.org/10.1002/mde.4090160603

[9] Fitza, M. and Mosakowski, M.E. (2009) Do VCs Matter? The Importance of Owners on Performance Variance in Start-Up Firms. Strategic Management Journal, 30, 387-404. https://doi.org/10.1002/smj.748

[10] Inderst, R. and Mueller, H.M. (2009) Early-Stage Financing and Firm Growth in New Industries. Journal of Financial Economics, 93, 276-291. https://doi.org/10.1016/j.jfineco.2008.07.004

[11] Zaborowski, J. (2009) Opportunities in a Recession. Economic Development Journal.

[12] Colombo, M.G., D'Adda, D. and Pirelli, L.H. (2016) The Participation of New Technology-Based Firms in EU-Funded R\&D Partnerships: The Role of Venture Capita. Research Policy, 45, 361-375. https://doi.org/10.1016/j.respol.2015.10.011

[13] Bottazzi, L. and Rin, M.D. (2002) Venture Capital in Europe and the Financing of Innovative Companies. Economic Policy, 17, 229-270. https://doi.org/10.1111/1468-0327.00088

[14] Higashide, H. and Birley, S. (2002) The Consequences of Conflict between the Venture Capitalist and the Entrepreneurial Team in the United Kingdom from the Perspective of the Venture Capitalist. Journal of Business Venturing, 17, 59-81. https://doi.org/10.1016/S0883-9026(00)00057-4

[15] Gomez-Mejia, L.R., Balkin, D.B. and Welbourne, T.M. (1990) Influence of Venture 
Capitalists on High Tech Management. The Journal of High Technology Management Research, 1, 103-118. https://doi.org/10.1016/1047-8310(90)90016-W

[16] Tyebjee, T.T. and Bruno, A.V. (1984) A Model of Venture Capitalist Investment Activity. Management Science, 30, 1051-1066.

https://doi.org/10.1287/mnsc.30.9.1051

[17] Sapienza, H.J., Amason, A.C. and Manigart, S. (1994) The Level and Nature of Venture Capitalist Involvement in Their Portfolio Companies: A Study of Three European Countries. Managerial Finance, 20, 3-17. https://doi.org/10.1108/eb018456

[18] Knockaert, M., Lockett, A., Clarysse, B. and Wright, M. (2005) Do Human Capital and Fund Characteristics Drive Follow-Up Behaviour of Early Stage High Tech VCS?

[19] Macmillan, I.C., Kulow, D.M. and Khoylian, R. (1989) Venture Capitalists' Involvement in Their Investments: Extent and Performance. Journal of Business Venturing, 4, 27-47. https://doi.org/10.1016/0883-9026(89)90032-3

[20] Amit, R., Glosten, L. and Muller, E. (1993) Challenges to Theory Development in Entrepreneurship Research. Journal of Management Studies, 30, 20. https://doi.org/10.1111/j.1467-6486.1993.tb00327.x

[21] Dushnitsky, G. and Lavie, D. (2010) How Alliance Formation Shapes Corporate Venture Capital Investment in the Software Industry: A Resource-Based Perspective. Strategic Entrepreneurship Journal, 4, 22-48. https://doi.org/10.1002/sej.81

[22] Bouresli, A.K. and Abdulsalam, W.N.D.I.A. (2002) Role of Venture Capitalists in IPO Corporate Governance and Operating Performance. Quarterly Journal of Business and Economics, 41, 71-82.

[23] Arcot, Sridhar (2014) Participating Convertible Preferred Stock in Venture Capital Exits. Journal of Business Venturing, 29, 72-87. https://doi.org/10.1016/j.jbusvent.2013.06.001

[24] Bernstein, S., Giroud, X. and Townsend, R.R. (2016) The Impact of Venture Capital Monitoring. The Journal of Finance, 71, 32. https://doi.org/10.1111/jofi.12370

[25] Barry, C.B., Muscarella, C.J., Iii, J.W.P. and Vetsuypens, M.R. (1990) The Role of Venture Capital in the Creation of Public Companies: Evidence from the GoingPublic Process. Journal of Financial Economics, 27, 447-471.

[26] Ni, J. (2012) Venture Capital Participation in Corporate Governance Impact on Performance. Doctoral Dissertation, East China University of Science and Technology.

[27] Rosenstein, J., Bruno, A.V., Bygrave, W.D. and Taylor, N.T. (1993) The CEO, Venture Capitalists, and the Board. Journal of Business Venturing, 8, 99-113. https://doi.org/10.1016/0883-9026(93)90014-V

[28] Hu, H.W., Tam, O.K. and Tan, G.S. (2010) Internal Governance Mechanisms and Firm Performance in China. Asia Pacific Journal of Management, 27, 727-749. https://doi.org/10.1007/s10490-009-9135-6

[29] Dutta, S. and Folta, T.B. (2016) A Comparison of the Effect of Angels and Venture Capitalists on Innovation and Value Creation. Journal of Business Venturing, 31, 39-54. https://doi.org/10.1016/j.jbusvent.2015.08.003

[30] Tian, X., Udell, G.F. and Yu, X. (2016) Disciplining Delegated Monitors: When Venture Capitalists Fail to Prevent Fraud by Their IPO Firms. Journal of Accounting \& Economics, 61, 526-544. https://doi.org/10.1016/j.jacceco.2015.09.004

[31] Hellman, T. and Puri, M. (2002) Venture Capital and the Professionalisation of 
Start-Up Firms: The Empirical Evidence. Journal of Finance, 57, 169-197. https://doi.org/10.1111/1540-6261.00419

[32] Kelly, P. and Hay, M. (2000) "Deal-Makers": Reputation Attracts Quality. Venture Capital, 2, 183-202. https://doi.org/10.1080/13691060050135073

[33] Gu, Q. and Lu, X. (2014) Unraveling the Mechanisms of Reputation and Alliance Formation: A Study of Venture Capital Syndication in China. Strategic Management Journal, 35, 12. https://doi.org/10.1002/smj.2117

[34] Sahlman, W.A. (1990) The Structure and Governance of Venture-Capital Organizations. Journal of Financial Economics, 27, 473-521.

https://doi.org/10.1016/0304-405X(90)90065-8 